\title{
Brug af peberspray i danske fængsler og arresthuse
}

\author{
Af Lisbeth Garly Andersen ${ }^{1}$ og Peter Vedel Kessing ${ }^{2}$
}

\begin{abstract}
This article discusses the use of pepper spray in Danish prisons and detention centers. Using qualitative interviews with prison officers and inmates as well as reviews of reports from prison officials about their use of pepper spray, the article examines whether the Danish rules and practices fully comply with human rights requirements and recommendations. The article offers insights into the situations in which pepper spray is typically used, where it is used and who it is used against. The article expresses concern about the use of pepper spray particularly in confined spaces and against mentally ill inmates. The authors argue that the use of pepper spray in Danish prisons should be more restrictive and more precisely regulated.
\end{abstract}

\section{Introduktion}

»Peberspray, det er så forfærdeligt, så man drømmer ikke om det. Man drømmer virkelig ikke om, hvor slemt det egentlig er i virkeligheden. Folk, de tror, det bare er noget, der svier hurtigt, og så kommer synet igen, det er det ikke, det gør virkelig, virkelig ondt at få peberspray, det gør det. Det svier i hele dit ansigt, og du kan ikke se noget, det er det værste. Det er det værste, at du ikke har overblik over, hvad der sker rundt omkring dig, du kan ikke se noget. Alt andet er bare når du åbner øjnene, er det bare sløret, og det svier så meget, at du dårligt nok kan holde dine øjne åbne. Det er virkelig modbydeligt. Det er det. Så hundrede procent, de må [hellere] brække min arm.« (Interview med indsat i dansk fængsel om, hvordan peberspray opleves, 2014)

Det blev i 2011 muligt at bruge peberspray som magtmiddel i danske fængsler og arresthuse. Modsat er peberspray ikke tilladt som magtmiddel i fængsler i Norge. I Sverige kan der anvendes peberspray, men kun i nødværge- og nødretlige situationer, navnlig hvor en indsat forsøger at flygte eller begår eller truer med at begå vold. I en nordisk sammenhæng adskiller Danmark sig således med en ganske liberal adgang til at anvende peberspray i fængsler og arresthuse.

* Title in English: Use of pepper spray in Danish prisons and detention centres. 
Siden indførelsen af pebersprayen i Danmark har Kriminalforsorgen gennemført to mindre evalueringer af magtmidlet, men der er herudover meget lidt viden om, hvordan peberspray anvendes, og hvilken betydning det har haft, bl.a. set i forhold til den samlede magtanvendelse. ${ }^{3}$ Samtidig har flere menneskeretlige institutioner, herunder Den Europæiske Menneskerettighedsdomstol, udtrykt bekymring over brugen af peberspray i fængsler og arresthuse, særligt i lukkede rum.

Ikke desto mindre blev fængselspersonalets adgang til at bære peberspray $\mathrm{i}$ fængsler og arresthuse yderligere udvidet i 2015. Personalet kan nu bære peberspray fast $\mathrm{i}$ en række situationer, f.eks. under transport og nattevagter, uden særskilt bemyndigelse fra en leder.

Institut for Menneskerettigheder besluttede på denne baggrund i 2014 at gennemføre en undersøgelse af brugen af peberspray i danske fængsler og arresthuse. Formålet med undersøgelsen var at belyse, hvordan peberspray anvendelsen i praksis, og vurdere om anvendelsen stemmer overens med Danmarks internationale menneskeretlige forpligtelser.

I denne artikel fremlægges de vigtigste resultater af undersøgelsen og de væsentligste anbefalinger. ${ }^{4}$ Herudover beskrives, hvilken reaktion undersøgelsen har afstedkommet i Kriminalforsorgen, og hvad der er sket efterfølgende.

\section{Anvendte metoder og kildemateriale}

For at få et indtryk af, hvordan peberspray anvendes i Kriminalforsorgen, er der i forbindelse med undersøgelsen anvendt kvalitative metoder i form af kvalitative interviews med fængselsbetjente og indsatte samt observation i udvalgte fængsler og arresthuse. Dette er suppleret med en dokumentanalyse af Kriminalforsorgens indberetninger om brug af peberspray som instituttet har fået aktindsigt i. De kvalitative metoder er efterfølgende kombineret med en juridisk analyse af gældende dansk ret og relevante menneskeretlige bestemmelser. De kvalitative metoder gennemgås nærmere i det følgende.

I planlægningen af undersøgelsen blev Statsfængslet i Nyborg, Køge Arrest og Københavns Fængsler ${ }^{5}$ foreslået som de vigtigste lokaliteter for undersøgelsen. Direktoratet for Kriminalforsorgen foreslog disse institutioner, da det er her, peberspray er blevet anvendt flest gange. Interviewene er blevet foretaget i nævnte institutioner, og det er indberetninger herfra, der er indgået i den efterfølgende sagsgennemgang. Undersøgelsen kan således give et indtryk af, hvordan peberspray anvendes i de tre institutioner og hvor peberspray anvendes oftest, men giver ikke et samlet billede af brugen af magtmidlet i samtlige af Kriminalforsorgens institutioner. En gennemgang af indberetninger om brug af peberspray $i$ andre fængsler i Danmark, som vi indledningsvis har foretaget, tyder dog på, at de 
situationer, peberspray bliver anvendt i, ikke umiddelbart adskiller sig fra institution til institution men, at den største forskel er, hvor hyppigt magtmidlet tages i brug.

Der er gennemført 20 interviews med betjente fra Nyborg Statsfængsel, Køge Arrest og Københavns Fængsler. Herudover er syv indsatte blevet interviewet, i alt 27 interviews. De interviewede betjente har alle enten selv anvendt peberspray, adviseret at peberspray ville blive anvendt eller set peberspray anvendt. De interviewede indsatte har alle været udsat for peberspray en eller flere gange. Udover interviewene har forskeren fulgt de daglige aktiviteter i fængslerne over fire dage. Alle interviews og observationer har fundet sted i perioden januar 2014 til april 2014.

Interviewpersonerne er dels blevet udvalgt af ledelsen på de forskellige institutioner, dels af instituttet selv. På hver institution har forskeren indledningsvis interviewet ledelsen som så herefter har foreslået nogle informanter (betjente såvel som indsatte). Instituttet har herefter selv udvalgt en del af informanterne. Instituttets udvælgelse af interviewpersoner er sket udfra ønsket om at sammensætte en så repræsentativ informantgruppe som muligt i forhold til både interviewpersonernes køn, alder, funktion og placering i institutionen, men også udfra, hvad der var praktisk muligt i den givne situation (bl.a. hvem der havde tid til et interview og gav udtryk for interesse i at blive interviewet). De interviewede betjente indgik på forskellige niveauer i organisationen, som henholdsvis ledere og overvagtmestre (7 interviews) og som almindelige fængselsbetjente (13 interviews). Betjentene var tilknyttet forskellige afdelinger, herunder bl.a. afsnit med fællesskab, sygeafsnit og afsnit med strafceller. Både kvindelige og mandlige betjente blev interviewet. De interviewede indsatte afsonede på forskellige afdelinger og var alle mænd. Nogle havde været indsat en kortere periode, mens andre havde en længere afsoning bag sig. Helt unge indsatte er blevet interviewet såvel som lidt ældre indsatte. En enkelt talsmand for de indsatte er blevet interviewet.

Interviewene med betjentene foregik på en række forskellige lokaliteter i institutionerne, herunder kontorer, overvågningsrum, bibliotek, frokoststue osv. Interviewene med de indsatte foregik i besøgs- og advokatrum uden betjentes tilstedeværelse og $\mathrm{i}$ et par tilfælde på en leders kontor.

Hovedparten af interviewene er blevet optaget og elleve interviews er blevet transskriberet. To forskere var til stede under fem af interviewene, hvor den ene nedskrev interviewet direkte. Ellers var der kun en forsker til stede, også de dage, hvor der primært var tale om at følge dagligdagen i fængslet.

I forbindelse med undersøgelsen er der analyseret 86 indberetninger om brug af peberspray fra Statsfængslet i Nyborg, Køge Arrest og Københavns Fængsler. 
Indberetningerne dækker perioden fra indførelsen af peberspray (juni 2011) til og med januar 2014, hvor nærværende undersøgelse blev påbegyndt. Indberetningerne har form af et skema betjentene har pligt til at udfylde hver gang de har benyttet peberspray mod en indsat.

\section{Samlet magtanvendelse i tal}

Brug af magt i fængsler og arresthuse er reguleret i $\S 62$ i straffuldbyrdelsesloven (herefter sfbl.), der indeholder en udtømmende opregning af hvilken magt, Kriminalforsorgen kan anvende, nemlig greb, skjold, stav, peberspray og tåregas. ${ }^{6}$

Der er ikke noget retligt hierarki mellem de fem tilladte magtmidler. Det adskiller sig fra politiets brug af magt, hvor det retlige udgangspunkt er, at politiet først skal anvende almindelig fysisk magt (dvs. tale, håndkraft og greb) og først derefter - hvis almindelig magt viser sig uegnet eller utilstrækkelig - kan anvende magtmidler, herunder peberspray.

Siden peberspray er blevet tilladt i fængsler og arresthuse i 2011 er det blevet brugt 56 gange i 2012, 70 gange i 2013 og 81 gange i 2014. Oversigten viser, at peberspray bruges mere end tåregas (5 gange i 2014), stav (18 gange i 2014) og skjold (37 gange i 2014) tilsammen.

Inden indførelsen af peberspray som magtmiddel i Kriminalforsorgens institutioner i 2011 blev der primært brugt håndkraft (greb), og dette er fortsat den mest almindelige måde at anvende magt på (970 gange i 2014).

En gennemgang af tal fra Kriminalforsorgen viser, at den samlede magtanvendelse er steget i Kriminalforsorgen siden 2002. ${ }^{7}$ Dette gælder både anvendelsen af håndkraft, stav og skjold. Tallene viser endvidere, at indførelsen af peberspray ikke har ført til et fald $i$ anvendelsen af de øvrige magtmidler med undtagelse i 2011, hvor tåregas og skjold slet ikke blev anvendt. Peberspray er således blevet et ekstra, supplerende magtmiddel for betjentene, og et meget "populært« magtmiddel - det mest benyttede magtmiddel bortset fra greb.

\section{Hvad er peberspray og er det farligt?}

Peberspray er en væske, der består af et peberekstrakt, der ved hjælp af en drivgas sprøjtes mod den, som den koncentrerede stråle rettes imod. Det aktive stof i peberspray er capsaicin (oleoresin capsicum). Peberspray virker i en afstand på op til 6-7 meter og påfører den ramte person akut øjenkrampe med deraf følgende midlertidig blindhed, som normalt varer ca. 30-45 minutter. Derudover bliver personen påført stærk smerte i øjnene og hudsvie, slimhindeirritation og luftvejspåvirkning i form af hoste. Den ramte bliver desorienteret og føler ubehag. ${ }^{8}$ 
I Den Uafhængige Politiklagemyndigheds årsberetning for 2013 anføres tilsvarende, at »den ramte person vil krumme sig sammen og være fuldstændig blændet og uden mulighed for at orientere sig, ligesom vedkommende vil have stærke smerter «. ${ }^{9}$

I forbindelse med overvejelserne om at indføre peberspray vurderede Sundhedsstyrelsen de medicinske skadevirkninger ved anvendelse af peberspray. Sundhedsstyrelsen fandt sammenfattende, at der kan være alvorlige helbredsrisici forbundet med at anvende peberspray, særligt hvis den eksponerede person lider af luftvejssygdomme eller er påvirket af rusmidler. Herudover konstaterer Sundhedsstyrelsen, at der findes rapporter om alvorlige læsioner i hornhinden, der ser ud til at skyldes kemisk ætsning på grund af opløsningsmidler, der er anvendt i pebersprayen.

At peberspray er et potentielt farligt magtmiddel fremgår også af Østre Landsrets dom fra 2010 om en privat borgers anvendelse af peberspray. Et afgørende spørgsmål i sagen var, om den tiltalte skulle dømmes for »almindelig vold « efter straffelovens $\S 244$ eller efter $\S 245$, som vedrører vold af »særlig, rå, brutal eller farlig karakter. Afgørende for, om et voldsangreb er af »særlig farlig karakter«, er angrebets typisk farlighed, ikke om det i det konkrete tilfælde har medført alvorlig skade.

Landsretten fandt, at angrebet med peberspray »på grund af den betydelige smerteforvoldelse og generne med forbigående blindhed og risiko for alvorlig skade « måtte henføres under $\S 245$, som et angreb af særlig farlig karakter. Modsat kan det ikke antages, at magtmidlerne greb eller skjold i sig vil kunne omfattes af $\S 245$, da de typisk ikke er farlige. Mens den konkrete anvendelse af disse to magtmidler kan være farlig, er de ikke som peberspray generelt farlige (typisk farlighed).

Den Uafhoengige Politiklagemyndighed har endvidere i forhold til politiets brug af peberspray anført, at peberspray bør begrænses mest muligt under hensyn til, at der er tale om et magtmiddel udviklet med henblik på at påføre fysisk smerte $\mathrm{i}$ ikke ubetydelig grad. ${ }^{10}$

Det er således en række danske myndigheders vurdering, at peberspray er et alvorligt magtmiddel, der bør begrænses mest muligt.

\section{Fængselsbetjentes og indsattes beskrivelse af virkningen af peberspray}

Denne opfattelse kommer ikke til udtryk blandt fængselspersonalet. Vores undersøgelse viser, at fængselsbetjente generelt opfatter peberspray som det mest milde og skånsomme magtmiddel. ${ }^{11}$ 
En del betjente fremfører, at peberspray afføder færre skader end andre magtmidler, f.eks. stav og håndhændede greb. Dette er betjentenes indtryk og ikke noget, der er dokumenteret statistisk. Brugen af peberspray kan også hindre, at flere betjente skal trænge ind i cellen og f.eks. anvende greb, en form for magtanvendelse, som flere betegner som mere vidtgående. En udtalelse fra en betjent lyder f.eks.:

»Hvis vi har en indsat, og vi skal ind og tage ham, så vil vi være en tre-fire stykker når vi går ind og tager ham. Og det er klart, at den magtudøvelse, det er med fire mand eller kvinder, der foretager greb eller en benlås, påsætning af håndjern og alle de her ting, inden man tager ham ud af cellen, kan jo i den grad mindskes ved at bruge peberspray i stedet for « (IP 4). ${ }^{12}$

I følge betjentene er der herudover større risiko for at begå fejl, hvis flere betjente skal trænge ind i en celle til en ophidset person. En »fejlmargin« de ikke oplever i samme omfang med peberspray.

De indsattes evaluering af magtmidlet divergerer, ikke overraskende, fra betjentenes opfattelse. Sammenfattende viser undersøgelsen, at indsatte opfatter peberspray som et meget kraftigt magtmiddel. De opfatter det som kraftigt både fordi peberspray blænder øjnene og på grund af den konkrete smerte, der udløses og fordi de efterfølgende bliver forsvarsløse. Hovedparten af de syv interviewpersoner blandt indsatte udtaler således, at de hellere vil udsættes for henholdsvis håndjern, greb og stav (dog ikke slag på hovedet). Flere udtaler herudover, at de hellere ville skydes i benet end have peberspray.

Interviewpersonerne beskriver smerten i øjnene ved, at »øjnene løber i vand og lukker sammen « (IP 26), og som »grus og sand i øjnene« (IP 21) eller »som at få rockwool, glasfibre og sandpapir i øjnene« (IP 27). Alle beskriver, at de midlertidigt bliver blændede af peberspray, og at det i nogle tilfælde har varet i flere timer.

Samtidig påvirker peberspray vejrtrækningen. Den eksponerede hoster, og flere udtaler, at de ikke kunne trække vejret og var ved at blive kvalt. En person med astma beskriver, at hans hals hævede op, vejrtrækningen lukkede sig, og at han fik »blackout« (IP 23), en anden fortæller, at det føltes som at blive »druknet« (IP 24). Samtidig påvirker pebersprayen tåre- og slimkanaler, hvilket betyder, at tårer og snot løber.

Peberspray påvirker også huden, og der opleves en kraftig svien. Huden beskrives herudover som opsvulmet og varm eller rød og hævet, som hvis man »har barberet sig hårdt« (IP 26). Peberspray har endelig en ubehagelig lugt og klistret konsistens, der er vanskelig at fjerne fra beklædning og andre tekstiler. 
En informant forklarer:

»Det er som at få kogende vand i hovedet, det brænder og føles som sand. Man føler, at man ikke kan trække vejret. [...]. Man føler næsten, at man bliver kvalt, og øjnene vælter ud med tårer. Jo mere man gnider, jo værre bliver det« (IP 24).

Varigheden af pebersprayen beskrives forskelligt. Nogle oplever, at effekten af peberspray aftager efter et bad eller sanering, andre siger, at det kan føles helt op til en uge efter, fordi det bl.a. sidder i tøjet og i andre tekstiler. En person beskriver det på følgende måde:

»Jeg blev ved med at gå i bad, det brænder helt vildt. Og jeg kunne ikke forstå, at det blev ved med at brænde. Og så, det var så på tredje dag, og jeg havde skiftet tøj, [...] og så selv min jakke, den havde åbenbart noget peber stadigvæk, og det ætsede nærmest ned i min ryg, igennem jakke og det hele« (IP 27).

En af forklaringerne på at peberspray er værre end de andre magtmidler er, at peberspray ikke kan gradueres på samme måde, som greb og stav kan. Hvis en person f.eks. ikke længere gør modstand, når vedkommende udsættes for et greb, vil betjenten som regel slippe grebet lidt. Dette er ikke tilfældet med peberspray.

\section{I hvilke situationer kan der bruges peberspray og under hvilke beskyttelsesgarantier?}

I følge $\S 62$, stk. 1, i straffuldbyrdelsesloven må fængselsbetjente anvende peberspray mod indsatte, hvis det er nødvendigt i fire situationer (indikationsgrundene):

- For at afværge vold eller overvinde voldsom modstand,

- For at hindre selvmord eller anden selvbeskadigelse,

- For at hindre undvigelse eller standse undvegne eller

- For at gennemtvinge en påbudt foranstaltning, hvor en øjeblikkelig gennemførelse er nødvendig.

Såfremt en af de nævnte grunde er opfyldt, må fængselsbetjenten anvende peberspray. Men betjenten skal herudover iagttage nogle beskyttelsesgarantier. Betjenten skal altid sikre sig, at magtanvendelsen er nødvendig og, at den er proportional. Dvs. at magtanvendelsen skal stå i forhold til situationen. Magtanvendelsen skal herudover være så skånsom, som omstændighederne tillader. Den indsatte skal altid advares før brugen af peberspray og tilbydes afhjælpning af gener efter 
peberspray og lægetilsyn om nødvendigt. Beslutningen om at bruge peberspray eller anden magt træffes af fængslets leder eller den, der bemyndiges hertil.

I modsætning til hos politiet, er peberspray ikke en del af fængselspersonalets standardudstyr. Peberspray opbevares således som udgangspunkt i særlige peberspraydepoter i det enkelte fængsel eller arresthus.

Ved en ændring af Justitsministeriet magtanvendelsesbekendtgørelse i april 2015 blev fængselsbetjentes adgang til at bære peberspray udvidet. ${ }^{13}$ Hvor der før »konkret« skulle foreligge en særlig risikosituation, for at betjentene kunne bære peberspray, skal der nu alene foreligge en »særlig risikosituation«. Det er således ikke længere et krav, at der »konkret« foreligger en særlig risikosituation. Fængselsbetjente har dermed fået lov til at bære peberspray fast under transporter, på nattjeneste, på hospitalsvagter mm., på de institutioner, hvor de tidligere skulle hente pebersprayen i et depot (om nødvendigt) og ikke bar den fast. ${ }^{14}$

\section{Hvad udtrykkes i menneskerettighederne?}

Flere menneskeretlige organer har været kritiske over for brugen af peberspray $\mathrm{i}$ fængsler og arresthuse. Særligt brugen af peberspray i lukkede rum og brugen af peberspray over for personer, der allerede er under kontrol er blevet kritiseret. I det følgende præsenteres et generelt overblik over den menneskeretlige regulering og de vigtigste anbefalinger.

Den Europæiske Menneskerettighedskonvention (EMRK) indeholder en række bestemmelser, som er af betydning for nationale myndigheders magtanvendelse, herunder for politi og fængselspersonale. Navnlig forbuddet mod tortur, umenneskelig og nedværdigende behandling $i$ art. 3 er relevant i forhold til magtanvendelse over for indsatte i fængsler og arresthuse.

Den Europæiske Menneskerettighedsdomstol har indtil nu behandlet seks sager om brugen af peberspray. De fem sager vedrører politiets brud af peberspray i forbindelse med arrest og anholdelser. Kun en sag vedrører brug af peberspray i et fængsel.

Det drejer sig om Tali 13/2 2014 mod Estland. I den sag var klager i 2001 blevet idømt livstidsfængsel for drab på to personer og forsøg på drab på en tredje person og afsonede i et estisk fængsel. Under fængselsopholdet var han dømt flere gange for at angribe fængselspersonale og andre indsatte. Han havde tillige under afsoningen modtaget 29 disciplinærstraffe for ikke at adlyde påbud og true fængselspersonale. I forbindelse med at klager skulle flyttes fra egen celle til en straffecelle for at afvikle en disciplinærstraf, nægtede klager frivilligt at forlade sin celle. Fængselsbetjente trængte derfor ind i hans celle med plastikskjolde, be- 
skyttelsesdragte og hjelme. Der opstod håndgemæng, og klager blev med magt flyttet til straffecellen.

Klager påstod, at han i den forbindelse brækkede et ribben. Dagen efter ville klager ikke frivilligt udlevere en madras fra straffecellen på trods af gentagne anmodninger herom fra fængselspersonalet. Seks fængselsbetjente ankom derefter til klagers celle. To vagter gik ind i cellen. Den ene vagt tog klager i hånden og sagde, at de ville tage madrassen. Klager trak hånden til sig (ifølge staten skubbede klager til fængselsbetjenten), hvorefter fængselsbetjenten uden advarsel sprayede ham med peberspray i øjnene. Derefter opstod der slagsmål mellem vagterne og klager. Klager blev slået med stav og til sidst overmandet, tvunget ned på gulvet og iført håndjern. Senere blev klager fikseret til en seng i en særlig sikkerhedscelle.

Klager påstod, at han var blevet udsat for behandling i strid med art. 3. Fra statens side blev det gjort gældende, at den anvendte magt var nødvendig og proportional, samt at peberspray var den mindst skadelige måde (»least injurious method available«), hvorved vagterne kunne få den farlige fange under kontrol.

Domstolen fandt, at brugen af peberspray var uberettiget (»the circumstances did not justify the use of pepper spray«) under henvisning til de potentielt alvorlige virkninger, peberspray kan føre til ved brug i lukkede rum (»confined spaces «), samt til at fængselsbetjentene kunne have benyttet andre magtmidler (som de havde gjort dagen før), herunder plastikskjolde, beskyttelsestøj og hjelme (dommens præmis nr. 78).

Dommen viser, at der må udvises tilbageholdenhed med at anvende peberspray i lukkede rum, herunder i de indsattes celler. Det vil således kun være berettiget, hvis ikke det er muligt at anvende alternative metoder og magtmidler i form af f.eks. skjold.

Dommen lægger således også op til, at der skal være et retligt hierarki mellem magtmidlerne, således, at peberspray først anvendes, hvis beskyttelsesdragt, hjelm og skjold - og greb - ikke er egnede magtmidler.

FN's Handicapkonvention er også relevant fordi det følger af den, at personer med handicap, herunder psykisk syge, som frihedsberøves, har ret til tilpasning i rimeligt omfang, så der bliver taget hensyn til deres særlige behov. Det understreges endvidere, at staterne skal fremme passende undervisning af fængselsbetjente (artikel 13, stk.2). Denne tilpasningspligt betyder, at det kan være påkrævet at tage særlige hensyn til indsatte med psykisk sygdom, herunder at sikre, at de fysiske rammer og personaleressourcer er til stede for at forebygge eskalering af konflikter med indsatte med psykisk sygdom 
I tillæg til de nævnte konventioner er der i såvel FN som i Europarådet blevet udarbejdet en række anbefalinger og ikke-bindende retningslinjer (»soft-law «) for myndighedernes behandling af og magtanvendelse over for indsatte i fængsler og andre lukkede institutioner. Særligt kan fremhæves de såkaldte Europæiske Fængselsregler.

Ud over de nævnte regler og retningslinjer er udtalelser fra internationale besøgsorganer også relevante i forhold til vurderingen af peberspray i Danmark. Det drejer sig navnlig om udtalelser fra Den Europæiske Torturkomité (CPT). CPT besøger fængsler og andre lukkede institutioner og har i flere udtalelser forholdt sig til myndighedernes brug af peberspray i fængsler og lukkede institutioner.

CPT har bl.a. anført, at der skal være klare retningslinjer for anvendelse af peberspray, og at personalet skal være uddannet $\mathrm{i}$ brugen af det. CPT mener herudover ikke, at peberspray bør anvendes i lukkede rum, herunder heller ikke i den indsattes celle. Endelig anfører CPT, at peberspray skal rapporteres, at der skal være adgang til førstehjælp og læge, og at peberspray ikke bør være en del af betjentes standardudstyr.

\section{Fængselsbetjentes brug af peberspray i praksis}

For at få indtryk af, hvordan og i hvilke situationer peberspray anvendes, har Institut for Menneskerettigheder, som nævnt indledningsvist, gennemgået 86 indberetninger om brugen af peberspray og herudover interviewet 20 betjente og syv indsatte. De fleste af indberetningerne er fra Københavns Fængsler (53), herudover er der 20 sager fra Køge Arrest og 13 sager fra Statsfængsler i Nyborg.

I det følgende præsenteres gennemgangen af indberetningerne og betjentes beskrivelse af de situationer, hvor de anvender peberspray.

Undersøgelsen viser, at betjente som oftest kategoriserer deres magtanvendelse under kriteriet om afværgelse af truende vold og overvindelse af voldsom modstand. Sagerne fordeler sig som følger:

\begin{tabular}{|l|c|c|}
\hline Betjentes formål med anvendelse af peberspray & Antal sager & Andel \\
\hline Afværge truende vold og overvinde voldsom modstand & 61 & $71 \%$ \\
\hline Hindre selvmord og selvbeskadigelse & 16 & $19 \%$ \\
\hline Hindre undvigelse og standse undvegne & 5 & $6 \%$ \\
\hline Gennemtvinge en påbudt foranstaltning & 3 & $3 \%$ \\
\hline Begrundelse ikke oplyst & 1 & $1 \%$ \\
\hline
\end{tabular}




\subsection{Afvarge truende vold og overvinde voldsom modstand}

Omtrent to tredjedele af samtlige sager, hvor peberspray anvendes, henføres i kategorien »at afværge truende vold og overvinde voldsom modstand «. Sagerne spænder fra trusler om vold fra indsattes side til anvendt vold mod en eller flere betjente. I kategorien indgår også sager om overvindelse af modstand. I indretningerne er der skriftlige kommentarer fra fængselsbetjentene, hvor truslerne om vold beskrives som, at »den indsatte langer ud efter fængselsbetjenten«, »den indsatte gør et udfald mod fængselsbetjenten «, »indsatte farer op og går imod en fængselsbetjent«, »en indsat går truende frem mod en fængselsbetjent« eller »opfører sig truende«, og en indsat »hæver armene, som om han vil slå ud mod fængselsbetjenten«. Herudover nævnes indsatte, der »slår ud mod«, er »aggressiv og truende «, har »front mod personalet og knyttede hænder « og »løber frem mod betjenten«. I flere af sagerne beskrives de indsatte som »aggressive«, at de »slår og sparker på inventaret«, »skubber og råber til hinanden« og »råber og skriger«. I samme kategori indgår herudover situationer med reelle overgreb mod personalet, herunder knytnæveslag, at blive »nikket en skalle«, brug af spark og bid. Der er endvidere flere eksempler på, at indsatte kaster genstande af forskellig art, f.eks. inventar, mod betjentene.

Kategorien rummer også sager, hvor vold og trusler ikke er afgørende, men hvor den indsatte, efter betjentenes vurdering, yder forskellige former for modstand. Der ses eksempler på en indsat, der fremkommer med en verbal trussel mod en ansat og efterfølgende ikke vil efterkomme betjentens ordre, en indsat, der yder modstand mod at blive ført ud, en indsat, der forsøger at vride sig løs, og en indsat, der ikke vil lægge sig på gulvet. Herudover er der eksempel på, at peberspray anvendes for at få en indsat, der beskrives som ophidset, til »at falde ned «.

De interviewede betjente har brugt peberspray i situationer, de kategoriserer som »afværgelse af truende vold og overvindelse af modstand og trusler«. De beskriver situationer, hvor betjentene enten blev angrebet, afværgede et angreb eller følte sig truet. Der er eksempler på en betjent, der blev truet med en kniv, og en betjent, der blev ramt i hovedet af en indsats hånd, da den indsatte drejede sig aggressivt rundt. Der er herudover eksempler på en indsat, der var truende og slog til en betjents hånd, og en indsat, der var meget aggressiv og klar til at slås, som det forklares af en betjent. Enkelte betjente har også brugt peberspray over for indsatte, der var oppe at slås indbyrdes. F.eks. begrundes brug af peberspray ved, at de indsatte »skulle skilles ad « i en slåskamp. I et af eksemplerne holdt de indsatte ikke op med at slås, da de blev bedt om at stoppe, og peberspray blev herefter anvendt. 
Betjentenes egen sikkerhed er en vigtig begrundelse for, at peberspray er nødvendig. Flere betjente peger på, at de ville udsætte sig selv for fare, hvis de ikke brugte peberspray. En betjent siger f.eks., at magtanvendelse i nogle tilfælde finder sted, fordi »det er farligt for os, hvis vi ikke gør noget« (IP 1), og at det kan være nødvendigt »med magt at stoppe hans voldsomme adfærd« (IP 1).

Hvis betjentene tolker en indsats adfærd som truende, kan det være anledning til at anvende spray. Interviewene rummer en række eksempler på dette. I en situation blev der f.eks. brugt peberspray, fordi betjenten opfattede den indsattes bevægelser som optakt til, at han ville gøre »et udfald«. Betjentenes udtalelser viser, at kropssproget i sig selv kan have en stor betydning for, om en betjent føler sig truet. En betjent forklarer, at dette betyder mere end konkrete udtalelser:

»Det er kropssproget, ikke det verbale. Knyttede næver, tydelige blodårer, måden, de står på, spændt i kroppen, det tager jeg som et større faresignal end en, der står og siger, at han vil slå mig ihjel.« (IP 7)

Hvorvidt den enkelte betjent føler sig truet $\mathrm{i}$ en given situation, afhænger også af andre faktorer. Ifølge flere udtalelser har det f.eks. betydning, om truslen er personlig eller er rettet mod betjenten som autoritet. En betjent udtrykker, at hvis en indsat ikke vil følge anvisningerne, er det ikke en personlig trussel. Det opleves først som en trussel, når den indsatte "peger på mig som person« (IP 9). Om en indsat tidligere har begået overgreb mod betjente, har også indflydelse på, hvorvidt den enkelte betjent føler sig truet eller ej. En betjent beskriver, hvordan han ville reagere, hvis der var tale om en indsat, der allerede havde været dømt for vold mod en betjent:

»Hvis jeg kom ind til en, der sad inde på sengen og han fór op, ville jeg også give ham peber i hovedet. Hvis han tidligere har overfaldet en kollega, hvorfor skulle jeg så give ham chancerne for det igen?« (IP 16)

De gennemførte interview indikerer således, at oplevelsen af et være truet afhænger af flere faktorer. Vurderingen af de enkelte situationer afhænger herudover af den enkelte betjent. Som en leder udtrykker det, vil »vurderingen af, hvornår noget er farligt, være forskellig og bl.a. afhænge af den enkeltes baggrund og uddannelse (IP 1). Præcis hvornår peberspray skal anvendes, vil således være en subjektiv vurdering. 


\subsection{Hindre selvmord og selvbeskadigelse}

Af gennemgangen af indberetningerne fremgår det, at der er 16 sager, der angår hindring af selvmord og selvbeskadigelse. De fleste af disse sager angår hindring af selvbeskadigelse og de færreste decideret hindring af selvmord. I forhold til hindring af selvmord er der eksempler på en indsat, der har taget en ledning om halsen og står på en stol, en indsat, der står med et barberblad og truer med selvmord, og indsatte, der har taget en kniv op til halsen og truer med selvmord.

I sagerne angående selvbeskadigelse indgår sager med trusler om selvbeskadigelse, f.eks. indsatte, der har ødelagt en rude i deres celle og truer med at beskadige sig selv med glasset, eller indsatte, der truer med at anvende et barberblad og en kniv til selvbeskadigelse. Herudover er der sager, hvor den indsatte udøver reel selvbeskadigelse, f.eks. indsatte, der hamrer sit hoved mod henholdsvis en dør, en mur og en glasplade. Endelig er der sager, hvor betjentene kan se, at den indsatte har udøvet selvbeskadigelse, eksempelvis fordi vedkommende har synlige læsioner, og med denne begrundelse anvender peberspray.

Interviewene med betjentene indikerer, at flere betjente har anvendt peberspray i forbindelse med hindring af selvmord og selvbeskadigelse. De tilfælde, hvor peberspray er anvendt for at forhindre selvbeskadigende adfærd, omfatter en indsat, der havde knust en rude og truede med selvbeskadigelse, samt en indsat, der bankede sit hoved ind i væggen.

I de tilfælde begrundes magtanvendelsen af betjentene med hensyntagen til den indsattes sikkerhed og nødvendigheden af at stoppe selvbeskadigelsen. En betjent fortæller om en situation, hvor vedkommende kommer ind i en celle, og den indsatte havde et glas fra en knust rude i hånden. Den indsatte havde allerede skåret sig overfladisk $\mathrm{i}$ maven og truede med at skære sig selv $\mathrm{i}$ halsen. Efter at have prøvet at tale med den indsatte, anvendes peberspray. Med brugen af peberspray var hensigten at ville »chokere og passivisere den indsatte, så han fik noget andet at tænke på end at skære i sig selv« (IP 5).

\subsection{Hindre undvigelse og standse undvegne}

Gennemgangen af indberetninger resulterer i fem sager, hvor peberspray er blevet anvendt for at hindre undvigelse og standse undvegne. Sagerne omfatter en indsat, der forsøger at flygte under et hospitalsbesøg, en indsat, der forsøger at flygte ud af en politibil, såvel som undvigelse $\mathrm{i}$ forbindelse med retsfremstilling og domsafsigelse.

Der er ikke nogen af de interviewede betjente, der har anvendt peberspray i disse situationer, hvilket ikke er overraskende, da det forekommer forholdsvist sjældent. 


\subsection{Gennemtvinge en påbudt foranstaltning}

I forhold til kategorien »gennemtvingelse af en påbudt foranstaltning « er der tre indberetninger i perioden. Der er en sag om en indsat, der ikke vil slippe grebet i en anden indsat på gårdtursarealet. Herudover er der to sager, der minder om hinanden. I begge sager er de indsatte ophidsede og bliver bedt om at »træde tilbage«, i ét tilfælde at lægge sig ned. Da de ikke efterkommer dette, eksponeres de med peberspray. Der er heller ikke nogen af de interviewede betjente, der har anvendt peberspray i disse situationer, hvilket heller ikke er overraskende, da det forekommer forholdsvist sjældent.

\section{Hvor anvendes peberspray?}

I mere end halvdelen af sagerne (45 sager) anvendes peberspray i den indsattes celle. I otte sager anvendes peberspray i observationscelle. Peberspray bruges også i nogle tilfælde udenfor, primært på gårdtursarealet (18 sager). Når peberspray anvendes i en indsats celle, er der flere eksempler på, at døren lukkes efterfølgende, bl.a. for at undgå at fængselspersonalet eksponeres.

\begin{tabular}{|l|c|c|}
\hline Hvor anvendes peberspray? & Antal sager & Andel \\
\hline I egen celle & 45 & $52 \%$ \\
\hline På toilet/bruserum & 5 & $6 \%$ \\
\hline På gårdtur & 18 & $21 \%$ \\
\hline Udenfor & 3 & $3 \%$ \\
\hline På trappe/gang & 6 & $7 \%$ \\
\hline I elevator & 1 & $1 \%$ \\
\hline I observationscelle & 8 & $9 \%$ \\
\hline
\end{tabular}

De interviewede betjente har anvendt peberspray på gårdtursarealet og i forbindelse med, at en indsat skal føres fra en lokalitet til en anden. Det mest almindelige er dog, ligesom indberetningerne viser, at peberspray er blevet brugt mod en indsat, mens vedkommende er i cellen.

Efter peberspray er blevet anvendt i cellen, trænger betjentene typisk ind i cellen. Nogle gange lukker betjentene først døren et kort stykke tid. En betjent beskriver et scenarie som følger:

»Jeg kan udsætte dig for peber, og så kan jeg lukke døren til dig igen, og så kan du finde ud af, hvad du vil nu. Nu har du det her peber at forholde dig til. Når du er rolig, så kommer vi ind, og så tager vi dig, frem for at vi bare stormer ind, og så slås vi bare. Og den, der vinder, vinder, og så får vi sat håndjern på dig, og så er det ud af vagten.« (IP 4) 
Der er ingen af de interviewede betjente, der har hørt om tilfælde, hvor peberspray er benyttet under transport i køretøj. Hovedargumentet er ifølge betjentene, at det ikke er et optimalt magtmiddel, idet alle tilstedeværende i så fald ville blive eksponeret for peberet. Herudover peges der på, at der i en transportsituation heller ikke er optimale muligheder for at sanere vedkommende (personalets fagudtryk for at skylle øjnene med vand).

\section{Anvendelse af peberspray overfor psykisk syge indsatte}

Af betjentenes indberetninger fremgår det, at der i 15 af sagerne er gjort notater/observationer, der tyder på, at der er tale om anvendelse af peberspray mod indsatte med en psykisk sygdom eller en psykisk lidelse. I nogle af sagerne nævnes det eksplicit, at indsatte har en diagnose, f.eks. paranoid skizofreni. I andre sager nævnes medicin, der er uddelt til den indsatte, eller som den indsatte bruger, f.eks. Seroquel, der bl.a. anvendes til behandling af skizofreni og psykoser. I flere sager noteres det af lægen, at indsatte enten skal overflyttes til en psykiatrisk afdeling, eller at der skal bestilles et psykiatrisk tilsyn. I andre sager er det mere uklart, om indsatte har en psykisk sygdom eller en psykisk lidelse. En indsat beskrives f.eks. som selvmordstruet og psykisk uligevægtig. En anden indsat beskrives som »grådlabil med usammenhængende tale« og en som »urolig og vævende«. I nogle af sagerne har den indsatte herudover selv givet udtryk for at have det psykisk dårligt. I langt hovedparten af de 15 sager beskrives de indsatte tilmed som henholdsvis opfarende, hidsige eller udadreagerende, herunder at de »råber og skriger«. I flere af sagerne indgår ødelæggelse af inventar i cellen. I de 15 sager er der endelig medregnet fire sager, hvor indsatte enten har smurt sig selv eller cellen ind i fæces.

I interviewmaterialet er der eksempler på betjente, der har anvendt peberspray mod indsatte med psykiske sygdomme af forskellig art, eller som har kendskab til, at det er forekommet. ${ }^{15}$ Anvendelsen af peberspray har bl.a. fundet sted for at forhindre selvskadende adfærd.

Betjentene er i forbindelse med undersøgelsen blevet spurgt, om de mener, at indsatte med psykiske sygdomme er mere udsat for magtanvendelse end andre indsatte. De fleste betjente har svaret, at indsatte med psykiske sygdomme efter deres opfattelse er mere udsat for magtanvendelse end andre. Betjentene begrunder bl.a. dette ved, at indsatte med psykiske sygdomme kan være vanskelige at kommunikere med, hvilket dels kan skabe konflikter, dels kan betyde, at konflikter kan være sværere at nedtrappe igen. En betjent fortæller generelt om udfordringer i kommunikationen: 
»De psykisk syge kan du ikke forklare ting - de forstår ikke, hvad man siger. Blandt dem er der selvmordstruede, psykotiske og personer, der har taget en masse stoffer.« (IP 19)

Ifølge de interviewede betjente kan psykiske sygdomme give sig udslag i, at indsatte har »stærk truende adfærd « eller er »farlige«, hvilket har betydning for, om der anvendes magt. Ud over betjentens sikkerhed kan den indsattes egen sikkerhed være på spil, f.eks. hvis den indsatte er selvmordstruet eller udviser selvskadende adfærd. En betjent udtrykker således, at en stor del af magtanvendelserne netop handler om at beskytte den indsatte:

»En stor del af dem, vi anvender magt imod, har jo en eller anden form for psykiatrisk diagnose [...] og for en rigtig stor del af dem handler det jo om, at når vi går ind og anvender magt imod dem [...], så er det for at hindre, at de gør skade på sig selv.« (IP 3)

En anden grund til, at der forekommer øget magtanvendelse mod personer med psykiske sygdomme, er ifølge flere udtalelser, at nogle indsatte med psykiske sygdomme ikke forudser, hvad det betyder at bryde reglerne, ikke gennemskuer konsekvenserne og derfor ikke »retter ind «. Det kan medføre, at de ikke reagerer på forskellige påbud, eller som en betjent pointerer, »ikke indser, at det ikke kan betale sig « at protestere mod en given regel. Udfordringerne ses endelig også, når der er tale om en kombination af sproglige barrierer og psykisk sygdom/psykiske lidelser hos den indsatte. En betjent angiver:

»Hvis der er nogen, som er psykisk ustabile og samtidig ikke kan sproget, så står vi i en endnu vanskeligere situation. Og der er det jo sket, at situationen er blevet så tilspidset, så vi har været nødt til at bruge magt.« (IP 2)

\section{Er danske regler og praksis i overensstemmelse med menneskeretlige krav og anbefalinger?}

Vores undersøgelse viser, at der på en række området kan sættes spørgsmålstegn ved, om danske regler og praksis vedrørende brug af peberspray i fængsler og arresthuse lever fuldt op til de skitserede menneskeretlige krav og anbefalinger. I det følgende skitseres tre udvalgte problemområder og instituttets anbefalinger.

\subsection{Brug af peberspray i lukkede rum}

Den Europæiske Menneskerettighedsdomstol har som nævnt fastslået, at det er uberettiget at bruge peberspray i lukkede rum, hvis andre mildere magtmidler kan anvendes, f.eks. beskyttelsesdragt, hjelm, skjold og greb. CPT har skærpet dette og anført, at peberspray ikke bør anvendes i lukkede rum. 
Undersøgelsen af praksis viser, at ud af 86 sager er peberspray blevet anvendt 45 gange i indsattes egen celle og otte gange i observationscelle, det vil sige i en celle i mere end halvdelen af tilfældene. Interviewene indikerer endvidere, at der er eksempler på, at betjente i et kort tidsrum lukker celledøren efter anvendelse af peberspray. Instituttet anbefaler derfor, at det bør præciseres i loven, at peberspray som udgangspunkt ikke må anvendes i lukkede rum, hvis andre mildere magtmidler kan anvendes.

\subsection{Detaljerede retningslinjer}

De menneskeretlige organer stiller som nævnt krav om, at der skal være klare, detaljerede og bindende retningslinjer for anvendelse af peberspray. Af instituttets analyse fremgår det, at reglerne for fængselsbetjente kunne præciseres yderligere, idet reglerne er bredt formuleret og overlader et vidt skøn til Kriminalforsorgen. F.eks. er det upræcist hvad der menes med kategorien »truende vold og voldsom modstand.« I denne kategori er der registreret flere sager, hvor der ydes forskellige former for modstand - f.eks. en indsat, der ikke vil efterkomme en betjents påbud, eller en indsat, der ikke vil lægge sig ned. Spørgsmålet er om disse sager kan siges at udgøre »truende vold og voldsom modstand «? Ligeledes er den skønsmæssige indikationsgrund at »gennemtvinge en påbudt foranstaltning « ikke præcist afgrænset. ${ }^{16}$

\subsection{Retligt hierarki}

Menneskerettighedsorganer har forholdt sig kritisk til brug af peberspray i fængsler og anført, at peberspray bør begrænses mest muligt.

Hverken straffuldbyrdelsesloven eller magtanvendelsesbekendtgørelsen sondrer - modsat politireguleringen - mellem de forskellige tilladte magtmidler greb, skjold, stav, peberspray og tåregas. Der er ikke noget retligt hierarki mellem dem. Magtmidlerne kan anvendes i samme situationer og under iagttagelse af de samme betingelser.

Undersøgelsen af praksis indikerer, at fængselsbetjente generelt opfatter peberspray som det mest milde og skånsomme magtmiddel. Modsat denne opfattelse oplever indsatte peberspray som et særdeles ubehageligt og kraftigt magtmiddel. Desuden opfatter en række danske myndigheder såsom Sundhedsstyrelsen, Den Uafhængige Politiklagemyndighed og danske domstole peberspray som et alvorligt magtmiddel, der bør begrænses mest muligt.

I Sverige er det tilladt at bruge peberspray i nødværge- og nødretlige situationer. Men det er bemærkelsesværdigt, at der i den svenske regulering er et hierarki mellem, hvornår de forskellige magtmidler kan anvendes. Kan indgrebet gen- 
nemføres med greb (»kroppskraft«), må der kun anvendes peberspray, såfremt det konkret kan forudses, at de skadelige virkninger ved brug af peberspray er mindre end ved brug af greb.

Instituttet anbefaler på den baggrund at der $-\mathrm{i}$ lighed med reguleringen i politiloven - indføres et retligt hierarki mellem de tilladte magtmidler i straffuldbyrdelsesloven, således at greb er det mindst indgribende magtmiddel og peberspray et mere indgribende magtmiddel, der kun må benyttes, såfremt mindre indgribende magtmidler er åbenbart uegnede.

\subsection{Psykisk syge indsatte}

Som nævnt tidligere følger det af Den Europæiske Menneskerettighedskonvention og af FN's Handicapkonvention, at personer med en psykisk sygdom, der frihedsberøves har ret til tilpasning i rimeligt omfang for deres særlige behov. Det understreges endvidere i Handicapkonventionen, at staterne skal fremme passende undervisning af fængselspersonale. Dette betyder i praksis, at det kan være påkrævet at tage særlige hensyn til indsatte med psykisk sygdom og at sikre, at de fysiske rammer og personaleressourcer er til stede for at forebygge eskalering af konflikter med indsatte med psykisk sygdom.

Det fremgår af interviewene med fængselsbetjente, at indsatte med psykiske sygdomme kan være mere udsatte end andre for magtanvendelse bl.a. fordi betjente ikke har de fornødne kompetencer til at håndtere personer med sådanne problemstillinger. Instituttet mener derfor, at dette bør give anledning til at der iværksættes yderligere tiltag for at nedbringe magtanvendelse, herunder efteruddannelse af medarbejdere.

\section{Hvad sker der fremadrettet?}

På baggrund af analysen af menneskeretlige krav og anbefalinger og vores viden om praksis i fængslerne, mener Instituttet, at Kriminalforsorgen bør foretage nogle justeringen. Vi vil her afslutningsvis fortælle om, hvilke reaktioner undersøgelsen har afstedkommet i Kriminalforsorgen, og hvad der er sket efterfølgende.

Instituttet har løbende været i dialog med Kriminalforsorgen i forbindelse med gennemørelsen af undersøgelsen. Kriminalforsorgen har givet Instituttet adgang til tre fængsler og arresthuse, ligesom Instituttet har fået aktindsigt $i$ alle sager vedrørende peberspray i de udvalgte fængsler og arresthuse. Kriminalforsorgen har ydermere deltaget $\mathrm{i}$ undersøgelsens følgegruppe og er givet mulighed for at faktuelt at kommentere instituttets rapport, inden den blev udgivet. Instituttet byder altid sådan et samarbejde velkomment, men er samtidig opmærksom på, at et 
sådant samarbejde altid vil være en balance i forhold til formulering af en efterfølgende kritik af Kriminalforsorgen.

Ud over muligheden for at kommentere rapporten faktuelt, fik Kriminalforsorgen også mulighed for at kommentere rapportens anbefalinger, inden rapporten blev udgivet. Kriminalforsorgen gav her udtryk for, at de ville arbejde på at nedbringe antallet af magtanvendelser i lukkede rum, en af de væsentligste kritikpunkter ud fra en menneskeretlig synsvinkel.

Kriminalforsorgen har efterfølgende bl.a. indskærpet over for fængsler og arresthuse, at peberspray kun må bruges, hvis anden mindre indgribende magtanvendelse ikke er tilstrækkelig. Og at personalet skal være varsomme med at bruge peberspray i lukkede rum. Kriminalforsorgen har ydermere opfordret til at betjente søger mere dialog med de indsatte. Ifølge Kriminalforsorgen har både indskærpelsen og opfordringen ført til en markant nedgang i brugen af peberspray i 2015.

Kriminalforsorgen har endvidere tilkendegivet, at de vil se på, om de kan forbedre de eksisterende retningslinjer for brugen af peberspray i fængsler og arresthuse. Ligesom de vil søge at indføre et retligt hierarki for magtanvendelse i lighed med det, som anvendes hos politiet og som kendes i Sverige. Således at der først kan anvendes samtale; dernæst håndkraft/skjold; peberspray; tåregas og til sidst stav.

Det er en positiv udvikling ikke mindst i lyset af at personalets muligheder for at bære peberspray samtidig er blevet udvidet i 2015. En udvikling som vi via vores mandat som National Menneskerettighedsinstitution vil fortsætte med at følge.

\section{Noter}

1. Lisbeth Garly Andersen er antropolog og ansat som specialkonsulent på Institut for Menneskerettigheder.

2. Peter Vedel Kessing er cand.jur., ph.d. og ansat som seniorforsker på Institut for Menneskerettigheder og ekstern lektor på Juridisk Fakultet, Københavns Universitet.

3. For så vidt angår politiets brug af peberspray se Lars Holmberg, Politiets brug af peberspray: en skandinavisk sammenligning med fokus på Danmark, Nordisk Tidsskrift for Kriminalvidenskab, Vol. 100, No. 1, 2013, side 89-111. Se også Dansk Institut for Menneskerettigheder, Brug af peberspray i dansk politi, 2015. Rapporten kan findes her: http://menneskeret.dk/files/media/dokumenter/udgivelser/peberspray_politi_2015.pdf

4. Selve undersøgelsen kan findes her: http://www.menneskeret.dk/udgivelser/brugpeberspray-danske-faengsler-arresthuse 
5. Københavns Fængsler er Kriminalforsorgens største lukkede fængsel og arresthus og udgøres af Vestre Fængsel, Blegdamsvejens Fængsel, Politigårdens Fængsel og Nytorvs Fængsel.

6. For en nærmere gennemgang af straffuldbyrdelseslovens bestemmelser om magtanvendelse se Jakob Schiøler, Straffuldbyrdelseslovens bestemmelser om indgreb over for indsatte, DJØF, 2012.

7. http://www.kriminalforsorgen.dk/Årlige-statistikberetninger-1365.aspx.

8. Beskrivelsen stammer fra det lovforslag, hvor peberspray blev indført som magtmiddel i Kriminalforsorgen, jf. lovforsalg nr. L. 93, Lov om ændring af lov om fuldbyrdelse af straf mv., fremsat d. 8. december 2010, pkt. 2.1.2, side 3.

9. Den Uafhængige Politiklagemyndighed, Årsberetning 2013: 13.

10. Den Uafhængige Politiklagemyndighed, Årsberetning 2013:13.

11. Jf. nærmere instituttets rapport, note 2: 52-54.

12. Med IP menes interviewperson. Af hensyn til at sikre interviewpersonernes anonymitet er alle interviews blevet tildelt et nummer, som der henvises til ved citering.

13. Jf. Justitsministeriet, Bekendtgørelse om anvendelse af magt over for indsatte i kriminalforsorgens institutioner (magtanvendelsesbekendtgørelsen), BEK nr 588 af 30/04/2015.

14. Jf. Justitsministeriet, Direktoratet for Kriminalforsorgen, Skrivelse om bekendtgørelse om anvendelse af magt over for indsatte i kriminalforsorgens institutioner, SKR nr 9267 af 30. april 2015.

15. Betjentene har i deres besvarelser ikke forholdt sig til, om en indsat har en psykisk lidelse eller en psykisk sygdom. De anvender typisk betegnelsen psykisk syge. Dette er imidlertid ikke nødvendigvis udtryk for en lægelig vurdering, men er udtryk for den måde, betjentene har beskrevet vedkommende på. Der kan således være indsatte, som betjentene betegner som psykisk syge, men som lægeligt set har en psykisk lidelse. Forskeren har brugt begrebet psykisk syge $\mathrm{i}$ interviewene, men ikke afklaret begrebet med betjentene.

16. Se i samme retning Jakob Schiøler, jf. note 6, side 235-236. 